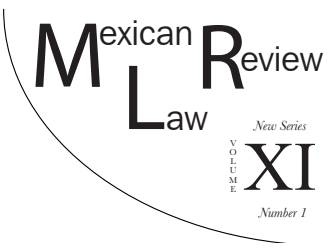

\title{
HUMAN RIGHTS EDUCATION AND TRAINING PROGRAMS IN MEXICO: A CROSS-CASE ANALYSIS OF PRACTITIONERS' PROFESSIONAL KNOWLEDGE AND PRACTICES
}

\author{
Gabriela MARTínEZ SAINZ*
}

\begin{abstract}
In Mexico, human rights education and training programs are becoming one of the most recurrent outcomes in official settlements related to institutional violations and abuses of human rights. Despite their predominant role in addressing human rights violations, there is little systematic information on how these programs are conducted in practice. To fill the gap, this article presents a cross-case analysis of three qualitative studies that explore practitioners' professional knowledge and practices in implementing human rights education programs in Mexico. Each individual case examines some of the challenges practitioners face in the implementation of these programs, the institutional influence on their work, and the role of their own experiences in human rights practices.
\end{abstract}

* Co-founder and Director of Centro de Estudios en Derechos Humanos, an independent and not-for-profit think tank that develops research-led and evidence-based projects to eradicate violence and discrimination, advance social justice and strengthen respect for human rights across Latin America. She holds a PhD in Education and a Master's Degree in Educational Research from the University of Cambridge where she conducted research on the implementation of human rights education and training programs in Mexico. As a researcher, Gabriela is a member of the National System of Researchers in Mexico, certified by the National Council of Science and Technology. She has been affiliated with the Centre for Governance and Human Rights of the University of Cambridge, and the Centre for Socio-Legal Studies at the University of Oxford, where she collaborated on the UNESCO-funded project "Countering Online Hate Speech.” Email: gms@cedhmx.org

This work was supported by Cambridge Trusts; the National Council on Science and Technology in Mexico; and the Secretary of Public Education in Mexico. I wish to thank the Centre of Governance and Human Rights at University of Cambridge and the Latin American Centre at University of Oxford, where I presented early drafts of this article. I benefited from the discussion and suggestions given by Dr. Ella McPherson, Professor Laurence Whitehead, Dr. Ian Frowe and Professor Keith Taber. I also want to thank Dr. Daniel Vazquez for his helpful insights and discussion. 
Esta revista forma parte del acervo de la Biblioteca Jurídica Virtual del Instituto de Investigaciones Jurídicas de la UNAM http://www.juridicas.unam.mx/

DOI: http://dx.doi.org/10.22201/iij.24485306e.2018.1.12513

KEYWORDS: human rights practice; human rights education; military training; practitioner's knowledge; training practices.

Resumen: En México, los programas de educación y capacitación en derechos humanos se están convirtiendo en uno de los resultados más recurrentes en las recomendaciones y dictámenes oficiales en relación a violaciones institucionales y abusos contra estos derechos. A pesar del papel predominante de la educación y capacitación en el tratamiento a violaciones de derechos humanos, existe poca información sistemática sobre cómo estos programas se llevan a cabo en la práctica. Para subsanar el vacio que existe al respecto, este documento presenta un análisis cruzado de tres estudios cualitativos que exploran el conocimiento profesional y las prácticas de los profesionales en la implementación de programas de educación en derechos humanos en México. Cada caso individual examina algunos de los desafios que los profesionales enfrentan en la implementación de estos programas, la influencia institucional en su trabajo y el rol de sus propias experiencias en las prácticas de derechos humanos.

Palabras Clave: práctica de los derechos humanos; educación en derechos humanos; entrenamiento militar; conocimiento profesional; prácticas de capacitación.

\section{Table of Contents}

I. INTRODUCTION

II. HRE AND TRAINING.

III. Practitioners as Educators ....................................................... 109

IV. Professional Knowledge in HRE .............................................. 110

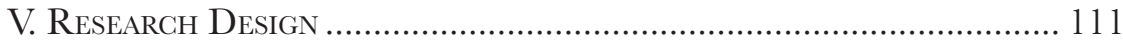

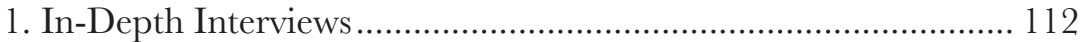

2. Think-Aloud Task ............................................................. 112

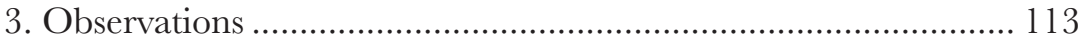

4. Document Analysis .............................................................. 113

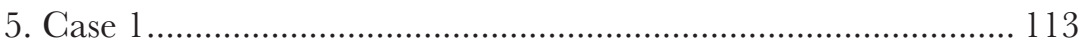

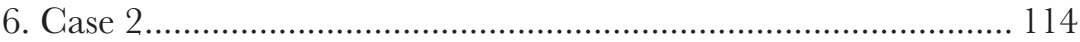

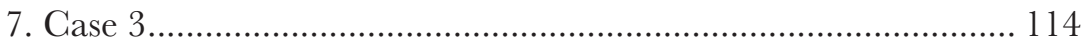



1. Learning to Teach Human Rights ........................................... 114

2. Defining What to Teach About Human Rights......................... 118

3. Translating Knowledge into Practice........................................ 119

4. Facing Professional Challenges .............................................. 122

VII. Discussion and Conclusions ....................................................... 126 
Esta revista forma parte del acervo de la Biblioteca Jurídica Virtual del Instituto de Investigaciones Jurídicas de la UNAM

\section{INTRODUCTION}

Mexico is at a critical and paradoxical moment with regard to human rights. On one hand, the number of cases of human rights violations and abuses has increased consistently since 2006. ${ }^{1}$ At least 22 human rights activists have been killed in crimes related to their advocacy work, with more than 245 attacks and abuses reported during this time. ${ }^{2}$ By 2012, 82 journalists had been killed and 16 more disappeared; in 37 of the cases the motives were confirmed as being related to their work, but only one of the 630 attacks against journalists has resulted in a criminal sentence. ${ }^{3}$ From 2006 to 2011 more than 170 cases of torture, 39 disappearances and 24 extrajudicial killings by state security forces were recorded, ${ }^{4}$ official figures for the most recent years remain unclear due to an arbitrary and flawed system of data collection. ${ }^{5}$ Nevertheless, at least 99 new cases of torture were being investigated at the beginning of 2013, ${ }^{6}$ eighteen more journalists were killed between 2013 and $2016,{ }^{7}$ and new cases of human rights abuses and violations which constitute crimes against humanity have been documented. ${ }^{8}$ These figures do not take into account the disparity between official reports and records provided by local Non-Governmental Organizations (NGOs), the latter reporting a higher number of human rights violations and abuses.

On the other hand, there has been significant progress regarding the legal framework and state policy on human rights. In 2011 the constitutional reform on human rights recognized all international treaties Mexico has signed and ratified as legally enforceable instruments in domestic courts and tribunals. ${ }^{9}$ The autonomy and mandate of the National Ombudsman has been extended; a new law regulating the use of public force has being devel-

1 UN [United Nations], Informe sobre la situación de derechos humanos en Mexico: actualización 2012 y balance 2013 (2013); Open Society Foundations, Undeniable Atrocities. Confronting Crimes Against Humanity in Mexico (2016); IACHR [Inter-American Commission on Human Rights], Situación de los derechos humanos en Mexico (2015).

2 UN, supra note 1.

3 Freedom House, Protecting Journalists and Human Rights Defenders in Mexico (2012), http://www.freedomhouse.org/sites/default/files/Protecting Journalists and Human Rights Defenders in Mexico.pdf; CPJ [Cомmittee to Protect Journalists], Journalists Killed in Mexico (2016); Gabriela Martínez Sainz, Theoretical Approaches to Human Rights Education, noviembre, 2011.

4 HRW [Human Rights Watch], Neither Rights Nor Security (2011).

5 Open Society Foundations, supra note 1.

${ }^{6}$ Silvia Otero, PGR indaga 99 casos de tortura en cinco meses, El UnIVERsal, October 21, 2013, http://wererceluniversal.com.mx/nacion-mexico/2013/impreso/pgr-indaga-99-casos-de-tortura-en-cincomeses-210161.html.

7 CPJ, supra note 3.

8 Open Society Foundations, supra note 1.

9 Segob [Secretaria de Gobernación de México], Reforma constitucional en MATERIA DE DERECHOS HUMANOS (2011) 
oped; and in 2012 a mechanism for the protection of human rights defenders and journalists was created. ${ }^{10}$ In addition, local and federal governments accepted more recommendations issued by the local ${ }^{11}$ and national human rights commissions in 2013 than in any previous years ${ }^{12}$ and have welcomed visits and reviews from international bodies on the situation of human rights in Mexico. ${ }^{13}$

It is within this paradoxical context that Human Rights Education (HRE) and training have gained momentum in Mexico. For activists and NGOs, HRE programs represent an attractive strategy in direct response to structural violence, and a sustainable way to prevent further abuses. ${ }^{14}$ These groups also employ HRE as a means of disseminating their work and as a path to influence policy implementation. HRE gives activists and NGOs a space to demand government accountability in the defense and protection of these rights. ${ }^{15}$ In addition, public organizations including local and national commissions for human rights have also promoted educational and training programs. As a preventive strategy or as a corrective measure within the recommendations they issue, these organizations rely on educational and training programs to prevent and reduce abuses and violations of human rights ${ }^{16}$.

Despite the important role assigned to HRE and training programs, there is limited information about the implementation and effectiveness of these programs. There are no official records of the programs developed by local NGOs, and those implemented by public organizations only report (if and when they do) on the number of activities and the total number of attendees. For instance, the National Human Rights Commission reported more than twenty thousand activities related to HRE and training between 2013 and 2015, which reached more than three million people. ${ }^{17}$ However, there is no information available regarding the design of these activities, their objectives, or their assessment and follow-up strategies (or lack thereof). Regardless of the momentum of HRE and training programs, and their growing role in

10 IAGHR, supra note 1; UN [United NATIONs], Informe PRELIMINAR DEL Grupo de Trabajo sobre el Examen Periódico Universal (2013)

11 In Mexico, in addition to National Human Rights Commission, each of the 32 states has a Local Commission with similar but focused particularly on the specific needs of the region.

$12 \mathrm{UN}, i d$.

13 IACHR, supra note 10.

14 Silvia L Conde, La educación en derechos humanos. Huellas del camino andado, in EDUCACión EN Derechos Humanos 147-177 (J.C. Gutiérrez Ed., 2006).

15 OSGE [Organization for Security and Co-operation in Europe] \& ODIHR [Office for Democratic Institutions and Human Rights], Guidelines on Human Rights Education for Human Rights Activists (2013).

16 GNdH [Comisión Nacional de los Derechos Humanos], Informe de actividades 2012 (2013).

17 GNDH, Informe de Actividades 2014 (2015); Informe de aCtividades 2013 (2014); INFORME DE ACTIVIDADES 2015 (2016). 
addressing human rights violations, little is known about how these programs are conducted in practice. Likewise, there is no research on how educational and training programs are implemented, nor on the challenges they face in the process. Nor is there empirical evidence on the relevance, pertinence and impact of these programs.

To fill this gap, this article presents a cross-case analysis of three qualitative case studies that explore practitioners' professional knowledge and practices in HRE programs in Mexico. Practitioners were selected as the focus of the study due to their first-hand knowledge of the implementation process of these educational programs, including their impacts and limitations. The cases presented below discuss the ways in which practitioners develop their professional knowledge to teach human rights, and how this translates into practice. The findings of the cross-case analysis reveal some of the contextual challenges practitioners face in the implementation of HRE programs in Mexico, how these challenges combine with institutional influences to shape individual experiences, and how these experiences impact the development of professional knowledge and practices. The findings of the case studies demonstrate the experiential nature of practitioners' professional knowledge in the field of HRE, which has individual as well as institutional implications for the implementation of educational and training programs in Mexico.

\section{HRE AND TRAINING}

Even though education has been considered an important means for the fulfilment of human rights since 1948, it is only in the last twenty years that HRE has gained importance as a field of its own. ${ }^{18}$ At the international level, the UN proclaimed the Decade for Human Rights Education from 1995 to 2004, developed the World Programme for Human Rights Education and Training in 2005, and in 2011 adopted the United Nations Declaration on Human Rights Education and Training. At the local level, HRE has gained particular importance in emerging democracies and post-conflict societies, ${ }^{19}$ NGOs and professionals increasingly rely on this educational model to frame their demands for social justice and adapt the language of human rights to local needs. ${ }^{20}$

The ultimate aims of HRE and training are twofold. First, they seek to provide individuals with relevant knowledge, skills and understanding of hu-

18 CP Henry, Educating for Human Rights, 13 Hum. Rights Q. 420-423 (1991); Felisa Tibbitts, Understanding What We Do: Emerging models for Human Rights Education, 48 InT. REv. Educ. 159-171 (2002); Educating for Human Rights and Global Citizenship, (Ali A Abdi \& Lynette Shultz Eds., 2008).

19 Tibbitts, supra note 18.

20 Monisha Bajaj, Human Rights Education: Ideology, Location, and Approaches, 33 Hum. RigHTs Q. 481-508 (2011). 
man rights. Second, they aim to empower individuals and foster the attitudes and behaviours needed for the protection and promotion of their rights. ${ }^{21}$ To do so, HRE and training encompass a wide range of educational and training activities aimed at conveying information, raising awareness and promoting understanding about, for, and through human rights. ${ }^{22}$ These activities include, but are not limited to: the design and publication of materials, the incorporation of content related to human rights in formal curricula and textbooks, implementation of courses, seminars and specialized programs at different levels, as well as public engagement and campaigns to raise awareness on human rights related issues.

HRE is designed to be as broad and flexible as possible so that it can be relevant for different people in different contexts. In this sense, it must to be able to convey relevant information on human rights according to the specific circumstances of the program, to address the interests and needs of diverse target groups, and finally, to develop approaches that empower individuals and foster their engagement with human rights. ${ }^{23}$ The breadth and flexibility of HRE, although considered two of its main advantages, ${ }^{24}$ also raise several challenges for the implementation of educational and training programs. The international model of HRE, developed by the United Nations, provides only general guidelines and recommendations, leaving the specificities of implementation to local governments and stakeholders, ${ }^{25}$ thus allowing plenty of leeway for domestic interpretation of the content, guidelines and objectives. These abstract guidelines do not take into account controversial issues regarding the implementation of educational programs and activities. Such issues include the complexity of the concept of human rights, ${ }^{26}$ the diversity of contexts where the programs are implemented, ${ }^{27}$ the competing ideologies underpinning HRE, ${ }^{28}$ and the diversity of teaching approaches that can be employed. ${ }^{29}$

21 UN, World Programme for Human Rights Education. Second Phase (2012).

22 UN, United Nations Declaration on Human Rights Education and Training (2011).

23 Felisa Tibbitts \& William R. Fernekes, Human Rights Education, in Teaching and Studying Social Issues: Major Programs and Approaches 87-117 (Samuel Totten \& Jon E. Pedersen Eds., 2010).

24 Nancy Flowers, How to Define Human Rights Education? A Complex Answer to a Simple Question, in International Perspectives in Human Rights Education (Viola B. Georgi \& Michael Seberich eds., 2004).

25 UN, supra note 1.

26 Margherita Rendel, Some Problems in Teaching Human Rights, in Human Rights, Education and Global Responsibilities 151-162 (James Lynch, Celia Modgil, \& Sohan Modgil eds., 1992).

27 Juliet Perumal, Identity, Identification and Sociolinguistic Practices: Implications for Human Rights Curriculum in an Emerging Democracy, in Safe Spaces. Human Rights Education in Diverse Contexts 63-82 (Cornelia Roux ed., 2012); Tibbitts, supra note 18.

28 Bajaj, supra note 20.

29 Claudia Lohrenscheit, International Approaches in Human Rights Education, 48 InT. Rev. EDUC. 173-185 (2002). 
Due to the diversity of activities and the broad aims pursued, HRE and training target a wide range of groups, ranging from school-age children to civil servants and law enforcement personnel..$^{30}$ Each of these groups has different needs in terms of content and strategies, but also specific interests concerning human rights, ${ }^{31}$ as a result, the rationale behind the programs can change drastically depending on the target group. For instance, most of the activities directed to children tend to be preventive and focus on awarenessraising ${ }^{32}$ whereas professional training for civil servants or law enforcement usually has a corrective nature and focuses on preventing further human rights violations and abuses. ${ }^{33}$ Considering all these differences, educational and training programs are a complex endeavour, particularly for those in charge of their implementation, in this case human rights educators. Educators act as mediators between human rights discourse, the objectives of HRE, and the realities of participants and stakeholders. ${ }^{34}$ It is precisely because of this mediation process and their leading role within it that educators represent a vital source of information for understanding the implementation of HRE and training programs and their scope, possibilities and limitations.

\section{Practitioners as Educators}

I use the term educators and not teachers or trainers since it better reflects the reality of a field like HRE. First, it acknowledges that the vast majority of individuals responsible for teaching human rights are not qualified teachers, though some of them may receive special training in pedagogy or teaching strategies. ${ }^{35}$ Second, it emphasizes the interdisciplinary nature of human rights and consequently HRE, which relies not only teachers but also those from other professions to teach all the relevant aspects and achieve the expected learning goals. ${ }^{36}$ Furthermore, the notion of educators is more representative of the field, considering that HRE and training programs commonly

30 UN, supra note 1.

31 Tibbitts, supra note 18.

32 OSCE \& ODIHR, Guidelines on Human Rights Education for Secondary School Systems (2012); CDHDF [Comisión de Derechos Humanos del Distrito Federal], La casa del árbol.

33 OSCE \& ODIHR, Guidelines on Human Rights Education for Law Enforcement Officials (2012).

34 Monisha Bajaj, Teaching to Transform, transforming to Teach: Exploring the Role of Teachers in Human Rights Education in India, 53 Educ. Res. 207-221 (2011); David Suárez, Education Professionals and the Construction of Human Rights Education, 51 Comp. Educ. Rev. $48-70$ (2007), http://werere.jstor.org/stable/10.1086/508638.

$35 \mathrm{UN}$, supra note 1.

36 Frank Elbers \& Kazunari FujiI, Summary of on-line forum on the Third Phase of the World Programme for Human Rights Education (2013), http://werere.hrea.org/lists/hreducation/. 
take place in the non-formal ${ }^{37}$ sector, ${ }^{38}$ rather than within formal educational facilities or programs.

Human rights educators require a particular kind of professional knowledge to address these issues, and to translate different educational and training programs on human rights into specific practices. They need to convert abstract guidelines into contextually relevant teaching practices, while also translating the discourse of human rights into intelligible parameters applicable to everyday life. ${ }^{39}$ Human rights ideas and principles may be difficult to comprehend for ordinary people ${ }^{40}$ increasing the complexity to the educators' endeavour. To do so human rights educators need professional knowledge on the theoretical principles of human rights, including instruments and norms, as well as an understanding of the context in which they are working and about the groups to which the programs are directed. In addition, they require some expertise in teaching approaches and pedagogical methodologies in human rights. Assessing educators' professional knowledge and practices is key to gaining a deeper and more comprehensive understanding of how HRE programs are actually implemented. ${ }^{41}$

\section{Professional Knowledge in HRE}

Despite of the role of educators' professional knowledge and practices for the application of HRE, there is no empirical research exploring them in detail. Research to date has focused on the role of educators' beliefs about HRE ${ }^{42}$ their ideological stances,${ }^{43}$ their teaching approaches,${ }^{44}$ their experiences teaching human rights, ${ }^{45}$ and some of their efforts to contextualize human rights discourse. ${ }^{46}$ Yet, none of these studies include educators' pro-

37 Non-formal education refers to organized and structured activities outside a formal educational system. These activities often lack accreditation or official certification, but they have a clear structure and objectives (Smith, 1996).

38 Henry, supra note 18.

39 Christine Bell, Teaching Human Rights : Teaching and Learning Manual (1999).

40 James Ron \& David Crow, Who Trusts Local Human Rights Organizations? Evidence from Three World Regions, 37 Hum. Rights Q. 188-239 (2015).

41 Ida Sabelis, Contemplations on Diverse Approaches for Human Rights Education, in SAFE SPACES. Human Rights Education in Diverse Contexts 259-268 (Cornelia Roux Ed., 2012).

42 Kevin Chin, Exploring Facilitators'Beliefs about Human Rights Education: Evidence of Universal and Local Influences, Res. Hum. Rights Educ. PAP. (2010).

43 BAJAJ, supra note 34.

44 Tiввiтts, supra note 18; Claudia Lohrenscheit, International Approaches in Human Rights Education, 48 Int. Rev. Educ. 173-185 (2002).

45 Audrey Osler \& Hugh Starkey, Teachers and Human Rights Education (2010); Safe Spaces. Human Rights Education in Diverse Contexts, (Cornelia Roux ed., 2012).

46 Rachel Wahl, Policing, Values, and Violence: Human Rights Education with Law Enforcers in India, 5 J. Hum. Rights Pract. 220-242 (2013). 
fessional knowledge in a comprehensive way, or examine their relationship with professional practices. In addition, there is a general lack of empirical research on the impact of educators' knowledge and practices in the implementation of HRE programs.

There is, however, extensive research in the development of professional knowledge and practices in education. Much of the literature has focused on the relationship between professional knowledge, experience and practice in formal education. ${ }^{47}$ Though such studies may shed some light on the application of knowledge within the teaching and training professions, they cannot provide significant insight specifically for HRE, since professional knowledge and practice are strongly influenced by the content and context of each particular field..$^{48}$ Thus, it is necessary to examine this knowledge by taking into consideration the nature of the subject of human rights, the particularities of the HRE model and the complexity of its implementation. For the examination of professional knowledge, the present study focuses on four of its core elements: 1) practitioners' knowledge (in this cross-case analysis this encompasses both human rights and how to teach them), 2) practitioners' processes of deliberation and reflection, 3) practitioners' teaching practices, and 4) the ends practitioners pursue. Without a deep examination of how educators think and act in their professional practice, we cannot fully understand complexity of HRE, its potential and its limitations. This research is particularly relevant in a context such as that of Mexico, where there is an increasing push towards HRE yet there are no official guidelines for its implementation. In this context, educators' narratives provide relevant insights for the development and assessment of current and future programs.

\section{Research Design}

Due to limited existing research on educators' professional knowledge and practice in HRE, the present study is exploratory in nature. Individual, indepth cases studies were selected as the methodology for this research, to allow for an exploration of complex social phenomena in a real-life context ${ }^{49}$

47 Lynn a. Bryan \& Sandra K. Abell, Development of professional knowledge in learning to teach elementary science, 36 J. Res. SaI. TEach. 121-139 (1999); Peter D. John, The teacher educator's experience: case studies of practical professional knowledge, 18 TЕACH. TЕACH. Educ. 323-341 (2002); John Loughran, What Expert Teachers Do. Enhancing professional knowledge for CLASSROOM PRACTICE (2010).

48 Phronesis as Professional Knowledge: Practical Wisdom in the Professions, (Elizabeth Anne Kinsella \& Allan Pitman Eds., 2012); Understanding And Researching Professional Practice, (Bill Green Ed., 2009).

49 Robert K. Yin, Case Study Research. Design and Methods (3rd Ed. 2003); Gary Thomas, How to do Your Case Study. A Guide for Students and Researchers (2011). 
while providing a comprehensive account of the relationships and process occurring within that context. ${ }^{50}$ This methodology allows the use of multiple points of data collection, which brings different perspectives to each case, and allows the triangulation of the data within each case so as to strengthen the rigor of the analysis. To ensure reliability and accuracy, each case was analyzed separately using the same analytical framework, and a constant comparison technique was applied.$^{51}$ Following the within-case analysis, I conducted a cross-case analysis using a case-ordered descriptive meta-matrix ${ }^{52}$ to compare and contrast emerging themes across the three individual cases. ${ }^{53}$

The data for the case studies were collected over a period of six months in Mexico, using the following methods:

\section{In-depth Interviews}

I conducted in-depth semi-structured interviews with each practitioner in the respective case studies. ${ }^{54}$ The interview protocol used in the three cases was the same, although the probes for follow-up and further exploratory questions changed according to the responses of each participant and the specific issues raised.

\section{Think-aloud Task}

This method of data collection focuses on the practitioners' reasoning process, problem-solving and decision-making. ${ }^{55}$ Each practitioner was presented with 26 statements on the definition, nature and implementation of human rights, and asked to what extent they agreed or disagreed with them. These statements were adapted from an earlier study conducted by Stenner on the subjective dimensions of human rights. ${ }^{56}$

\section{Observations}

50 Martyn Denscombe, The Good Research Guide for Small-scale Social Research Projects (4th Ed. 2010).

51 Robert K. Yin, Qualitative Research from Start to Finish (2011).

52 Matthew B. Miles \& Michael Huberman, Qualitative Data Analysis: An Expanded SOURCEBOOK (2n Ed. 1994).

53 Copies of the data collection protocols, coding and analysis frameworks are available from the author upon request.

54 Steinar Kvale \& Svend Brinkmann, InterViews (2nd Ed. ed. 2008).

55 Yvonne F Barnard \& Jacobijn A. C. Sandberg, The Think Aloud Method: A Practical Guide to Modelling Cognitive Processes (1994).

56 Paul Stenner, Subjective dimensions of human rights: what do ordinary people understand by 'human rights?, InT. J. Hum. Rights 1-19 (2010). 
I conducted participant observations of the practitioners' teaching activities in HRE programs. ${ }^{57}$ Participant observation as method of data collection provides unique insight into the behaviour and practices of the participants. ${ }^{58}$ The same unstructured, observational protocol was used for each session observed in each case study.

\section{Document Analysis}

Official publications and reports, program handbooks as well as teaching and learning materials were treated as data in each individual case. This method has been useful to research teaching practices in the past, ${ }^{59}$ as well as to access practitioners' input in the design and assessment of educational programs. Each document was analyzed using the same structured protocol. In addition, I used my field notes for contextual information and triangulation during data analysis. Documentary data helped to contextualize the other methods of data collection and to make sense of the experiences of the participants through the researcher's gaze. ${ }^{60}$

The three cases presented in this article were selected as representative of the three different institutions I worked with in Mexico, which were the National Human Rights Commission, a State Human Rights Commission in a geographically central state, and a local NGO in Mexico City. These institutions deliver educational and training programs in human rights, to varying extents according to their institutional guidelines, agenda and resources. Although each of the three institutions represent an in-depth case study, the institutional affiliation of individual practitioners is not revealed in order to ensure anonymity.

\section{Case 1}

Oscar has been working as an educator in human rights programs for more than six years. He grew up in one of the most culturally diverse states in Mexico, with more than 16 Indigenous communities accounting for the 18

57 Except for Case study 3, whose institution was planning the educational and training programs for the upcoming year at the time of my fieldwork.

58 Research Methods in the Social Sciences, Social Sciences (Bridget Somekh \& Cathy Lewin Eds., 2005).

59 Ruth Kane, Susan Sandretto \& Chris Heath, Telling Half the Story: A Critical Review of Research on the Teaching Beliefs and Practices of University Academics, 72 REv. Educ. Res. 177-228 (2002).

60 Research Methods in the Social Sciences, Social Sciences (Bridget Somekh \& Cathy Lewin Eds., 2005). 
percent of the Indigenous population of the country. ${ }^{61}$ Oscar graduated from law school, which is where he first came into contact with the subject of human rights. After his studies, he worked in the field of human rights at a local organization in his home state, although his was mainly an administrative job. Later, by invitation, Oscar joined the educational and training department at the institution where he currently works. He has specialized in comparative human rights law, especially in the Americas, with a postgraduate diploma from the Inter-American Commission on Human Rights (IACHR). Oscar's main areas of expertise within HRE are programs directed at military forces, police and other law enforcement officials.

\section{Case 2}

Anna has been part of an educational team responsible for HRE programs since she graduated with a Bachelor of Arts in Education over 13 years ago. This has been her only job and though she had no previous experience in human rights, she did an internship on development and education with disadvantaged communities. In the years she has worked in her institution, Anna has received a specialized training in human rights and HRE which is mandatory for all the members of her team. She must attend and pass refresher courses each year as part of her professional development plan. Anna's main areas of expertise are children's rights and peace education, environmental rights, and the rights of people with disabilities.

\section{Case 3}

Eric was a legal practitioner and human rights activist for more than 20 years before recently joining the organization in which he works as a human rights educator. He studied law and philosophy, and for some time he was part of a religious organization with a strong focus on education and social justice. Eric has experience prosecuting human rights cases at the national and international level and has received specialized training by United Nations and the IACHR. His main areas of expertise are related to the implementation of international instruments of human rights and the legal practice of human rights; he specializes in educational programs directed at judges and prosecutors, although he also works with other law enforcement officials.

\section{FINDINGS}

61 INegi, Perfil Sociodemográfico de la Población que Habla Lengua Indígena (2009). 
Esta revista forma parte del acervo de la Biblioteca Jurídica Virtual del Instituto de Investigaciones Jurídicas de la UNAM

\section{Learning to Teach Human Rights}

All three educators had a personal interest in human rights prior to working as educators in this subject. Even though their personal interests translated over the years into strong convictions on human rights and HRE, the three educators admitted that learning to teach human rights was a challenging process. One crucial aspect of this was the level of familiarity with human rights each educator had. Whereas Oscar and Eric had a fair amount of knowledge of this subject thanks to their legal studies, Anna, who comes from an education background, had no previous knowledge of human rights whatsoever. For her, the main challenge was her lack of understanding of the legal and theoretical issues connected to human rights. She acknowledged that her personal interest in issues of social justice served as motivation to develop a career in HRE, but agreed such an inclination was not prompted by an in-depth knowledge of the field:

Well, I didn’t know about human rights. It was only a personal interest [...] maybe with not much [theoretical] content, without many theoretical phrases, it gave me the empirical part. That is how I discovered later that those things had a name; they were human rights (Anna, semi-structured interview).

For Anna, the process of learning to teach human rights included a process of developing specialized and interdisciplinary knowledge of these rights, from legal and theoretical aspects to their application. As part of her learning process, Anna's background in education helped her develop the necessary skills to teach this topic, but as she later explained in the interview, that alone was not enough to grasp the particularities of HRE and her work as an educator.

In contrast, for Eric, the most difficult aspect of learning to teach human rights was related to the skills he had to develop rather than the content itself. Eric's studies in law and his years of experience defending victims of human rights violations as a legal practitioner helped him to gain specialized and practical knowledge about these rights. However, he felt at first that he lacked the skills to convey and communicate his knowledge or to advise learners in the exercise and application of human rights. Eric's previous knowledge of human rights and his familiarity with educational programs facilitated some aspects of his work as an educator, although he believed he still had to work on developing new ways of communicating to teach human rights. For him, creating appropriate channels of communication and strategies to reach people and engage them in the promotion and protection of human rights is a challenging and ongoing process.

Oscar argued that his background in law was an essential element of his professional knowledge and helped him as he was learning to teach human rights. For him, these rights can only be effectively exercised and enforced 
by having a strong understanding of their legal framework, which is why his legal knowledge has been key in providing learners with appropriate information on relevant instruments, laws and covenants. However, his lack of specific training in education and teaching made him feel like an "improvised" educator who had learned to teach human rights "on-the-go."

I am an amateur [...] I learned to teach human rights on-the-go. I must confess to you that I am an impromptu educator who developed [my knowledge] along the way. And to be honest, the topic of HRE is not my strongest point. It is something I have not mastered (Oscar, semi-structured interview).

Despite his legal expertise in human rights, Oscar felt insecure about his professional knowledge and teaching practices because, according to him, it was still challenging to convey this knowledge and explain it in an accessible way to participants. Without any pedagogical or teacher training, Oscar relied on his own experiences of learning about human rights, either in law school or at the IACHR, to develop his own professional knowledge and teaching approach.

All three educators agreed that their professional knowledge requires, on one hand, a deep understanding of human rights from an interdisciplinary perspective, including but not limited to: their legal framework and instruments, the theoretical principles underpinning these rights, and the different policies available to implement them. On the other hand, it also demands a fair comprehension of the educational process, teaching approaches and pedagogical strategies, as well as the identification of learning needs in order to understand how HRE can be effectively implemented for the advancement of human rights. However, as they explained, these two aspects can only be fully developed through experience over time. Experiential learning of professional knowledge became particularly evident for them when confronted with ethical dilemmas or when assessing the learning needs of a group.

For example, Anna stated that working with vulnerable populations including children who have suffered domestic or sexual violence posed serious ethical dilemmas to her professional knowledge, especially at the beginning of her career. In these instances she needed to ponder her own ethical responsibilities and professional duties over the needs and best interests of the child. For example, she had to make judgements such as whether or not to report a case, what information she should give to a child witnessing violence in her home, or how to proceed in a case in which someone insinuated abuse had occurred without explicitly reporting it. These judgements, according to Anna, were more challenging when she started teaching human rights, as she had no experience dealing with such cases. As a result, she felt she did not have reference points needed to approach this population or to assess the particularities of each case properly. Through experience, however, Anna has 
learned how to manage these cases in the best possible way for the children, while better coping with the emotional impact they have on her.

For Oscar, experience has helped him identify the learning needs of participants, and to adapt the content of his programs accordingly. He remembered the first time he taught police officers as having been a professional failure, as he was not prepared to address this population and had no institutional support or guidelines to follow. Over time, he has learned to identify the specific needs of police officers in the field of human rights, and he teaches them about instruments related to the legal use of force or how to incorporate international standards in their operations, for example, in a concrete way. Furthermore, Oscar has become familiar with the challenges police officers face and is now able to use these challenges to discuss legal instruments and ethical dilemmas related to human rights. Nevertheless, he felt that this experiential learning also has negative connotations. Oscar considers allowing novice educators to learn how to teach human rights through practice (by teaching) without any previous preparation unacceptable, because it is unfair to the learners who, in his view, become victims of the lack of training and professionalization of human rights educators.

Eric's teaching experiences have also facilitated a deeper knowledge of the populations he works with. When he started working with the army and police forces he was not familiar with their work or their perspective on human rights issues. Over time and as a result of teaching programs directed at them, he now has a comprehensive knowledge of the army in terms of military operations, hierarchy, and protocols. As he explained, it was only possible for him to acquire this knowledge and establish a strong relationship with soldiers and police officers after spending a considerable amount of time interacting with them during courses and seminars, listening to their opinions and taking into account their concerns when establishing the content of his programs. In addition, Eric has learned through his experience working as educator how to better design his courses to build upon learners' previous knowledge and experiences gradually. For instance, through a process of "trial and error" he has learned to divide the program that he imparts to judges and prosecutors into different stages, starting with basic concepts and definitions before helping them develop more specialized knowledge and skills on the implementation of human rights principles.

We also have an introductory level for [public servants] that have had no contact with the new [rights-based] system. In this case, you have to give them a lot of information for them to understand the differences and characteristics of this new system. Then we have the advanced [level] for those who have previous training on human rights and the new system (Eric, semi-structured interview) 
According to Eric, as a result of his teaching experience, he has learned to make professional judgements regarding participant learning, including decisions on when to move forward to a more complex level or when further teaching is needed. Thus, over time Eric has developed not only the skills to identify participant learning processes but also to adapt his program and teaching practices accordingly.

All three educators, regardless of the differences regarding their professional background or their level of familiarity with either human rights or education, agreed that experience was key in the development of their professional knowledge. The educators affirmed they have learned through experience but noted that in order to do so, they have had to reflect constantly on their practices and how to improve their teaching on human rights.

\section{Defining What to Teach About Human Rights}

The way in which each educator defined human rights had a strong impact on their conceptualizations of HRE and, therefore, the teaching practices that derive from it. For example, for Eric human rights must be relevant in practice and serve as political tools for social change. Thus, the efficiency and relevance of these rights relies on their application rather than their ratification in positive law or their recognition in legal instruments. For him, legal instruments are useless if they are not applied, and this stance was reflected in his teaching practices, as he tried to deliver training programs that are transformational, practical, and relevant to social issues. For Eric, the main aim of HRE is the development of critical and active citizenship, and as such, he believes educational and training programs should focus on individual empowerment and social engagement, starting by raising awareness so individuals can advocate for their own rights. For this reason, in his teaching practice Eric pays special attention to the instrumental aspects of human rights and the capacity of these to solve social issues. One of the main aims of his programs is to change individual practices, which at the same time may be able to transform and improve institutional structures to encourage the promotion and protection of human rights.

[The goal] is not only that [judge or a procecutor] knows the theory, the ethical or legal aspects [of human rights] and that he is not supposed to torture. If the institution allows him to torture, he will keep using this strategy to advance a case, he can still use it as a [legitimate] tool for investigation. He will torture anyway, because regardless of what you tell him [during the course] he has incentives constructed by the institution to justify and advance the use of these resources [like torture] that should not be used. As long as there are no institutional modifications, changes to create other incentives, there is a risk that HRE is just a pretense (Eric, semi-structured interview). 
Similarly, Anna argued that human rights are first and foremost tools to fight for social justice. Although she acknowledged the different dimensions comprising these rights, in her view social and activist perspectives should be prioritized over legal or political ones in order to address structural issues and social problems. Thus, Anna favoured a practical and down-to-earth approach to HRE that takes into consideration individual and contextual needs.

For me this is something very important, and we have discussed it a lot within the team. It may not be explicit [in the curriculum] but most of [the educators] agree on this. For me it is enough that kids and young people come [to our programs], even if they apparently don't learn anything about human rights, only to realize that things can be different [...] It is important that they are able to see themselves as equal to an adult [...] to empathize with others' suffering $[\ldots]$ to respect each other, to discuss and share, and teach each other what we know (Anna, semi-structured interview).

Since Anna focused more on socio-emotional and moral aspects of human rights rather than legal or theoretical ones, for her the aim of HRE is to foster empathy as a means to promote and protect human rights. Thus, her courses and teaching strategies are designed to allow participants to experience an environment of respect and promotion of human rights in and through the program. Anna emphasized the importance of empathy in HRE, not only as a teaching strategy but also as a learning outcome. By doing so, Anna's concerns for social justice and equality were present throughout the programs, from the way she established and explained the content of human rights, to the group discussions she lead during the sessions.

Oscar interpreted human rights as social commitments and he established the overall aims and objectives of his teaching practices based on this interpretation. For him, HRE is a persuasive process to foster acceptance and conviction regarding human rights. Teaching human rights, then, is about presenting learners with a notion of human rights that is relevant, desirable, and convenient for their personal and professional circumstances. Learning about human rights is thus is a process of acceptance and of developing a strong conviction about rights that ultimately leads to changes in attitudes and behaviour. For Oscar HRE is a dialogical process to persuade learners, through respectful dialogue, about the importance of human rights rather than an imposition of these rights on them. Oscar's programs were designed to acknowledge first the challenges of learners' work related to the protection and promotion of human rights and then to raise their awareness regarding the relevance of these rights not only at a professional but also at a personal level. The influence of how each of the educators defined human rights and conceptualized HRE as a result was evident not only in Oscar's case but in all three cases. 


\section{Translating Knowledge into Practice}

Even though the teaching practices of the three educators shared some similarities regarding what they wish to accomplish during their programs, their objectives differed significantly when applied. For Oscar, Anna and Eric, the main aim of their practice was to raise awareness and foster personal conviction and commitment towards human rights among participants in their programs. All three of them agreed on the need to persuade individuals of the importance of human rights, because only through personal commitments can a sustainable culture of respect and promotion of rights be achieved. When asked about the strategies or practices they implemented to achieve this goal, the three educators provided different accounts and examples.

Oscar argued that he appeals to the rights of the participants to raise awareness and foster acceptance of the discourse of human rights. This is not an easy task, considering the mistrust of human rights among the groups he teaches, some of who still consider these rights a discourse that "only protects criminals." Through discussion of real-life cases concerning military and police officers, Oscar emphasized the relevance of human rights for participants in their work. He explained not only how respect for human rights and the application of the mechanisms that protect them in their daily work is beneficial for them and their interests, while also emphasizing the implications for them at a personal level. For this reason, Oscar's teaching practices relied constantly on the analysis of international instruments demonstrating how they can be implemented in real-life scenarios:

[Soldiers] ask you very interesting questions; for instance they asked me: 'Can I use my gun if the aggressor is pointing [a gun] at me?' And I tell them they can. This is when we analyze international instruments on human rights. We look at videos of real cases of criminals being captured; some of them were tragic situations where people have died. This is the kind of material that helps me the most (Oscar, semi-structured interview/observation).

For Oscar, a dialogical approach to his teaching practice is particularly relevant to addressing difficult and skeptical audiences like the military and police forces. He strongly believes that HRE could help to persuade the armed forces on the significance of human rights in Mexico generally, and for them in particular, even though they are the group with the largest record of complaints of human rights violations in the country. By establishing a dialogue with them, Oscar has learned about the particular challenges that soldiers and law enforcement officers face related to the protection of human rights. As he explained, their questions and even their objections to human rights are frequently discussed during his programs, and he has taken them into consideration in order to redefine the content he is teaching or the way he explains 
certain concepts. In doing so, his aim is to convey a more comprehensive and "down-to-earth" understanding of human rights that is relevant to them.

For her part, Anna appealed to participants' empathy in her teaching practices in order to raise awareness and encourage their commitment to human rights. She believed that the best approach to teaching human rights to children and young people was through experiential learning, giving them the opportunity to experience what it is like to exercise their own rights and identify alternatives to respect the rights of others. For Anna, the goal of her teaching strategies is to help participants to stand up for their rights by empowering them, but also to help them to become more empathic so they could care about the rights of others who express skepticism and mistrust towards these rights. To do so, Anna has developed several age-appropriate group strategies to discuss sensitive topics like bullying, sexual harassment, human trafficking and/or domestic violence. These activities and strategies are grounded in experiences that are relevant to them and their everyday lives. For instance, Anna has designed games that are appealing to participants, which at the same time facilitate the comprehension of abstract ideas like fairness, inclusion, or respect. These strategies served to explain the relevance of human rights and the mechanisms available for their protection, and ultimately, to discuss and reflect on the application of these rights in the lives of children.

Anna's teaching practices and the content of the programs she teaches are adapted to the specific needs of the group she is working with. However, due to the fact that she teaches vulnerable populations, she argued that most of the time these needs or specific circumstances become evident only after she starts working with the group, and she has to respond rapidly to them. Anna recalled how this happened to her when she was working with homeless children, she realized she needed to change her examples and explanations to address the participants' circumstances:

And then, what do I do? Here is where I have learned... What I should tell [the kid living on the streets], so what I say won't hurt him... If you tell street-kids... the homeless population: 'You have the right to have a family,' [They will reply] What? Because [for them] their family is their 'gang.' Then you need to learn to explain to them: 'The right to have a family is to have someone to look after you, who cares about you... you can call it dad, grandmother, aunt, brother... or your gang...' and then the whole discourse changes (Anna, semi-structured interview).

According to Anna, learning to teach human rights to vulnerable populations implies finding the best way to approach them and making the content of the programs relevant to them. This is one of the most complex challenges she has faced as an educator. Because of this, Anna's teaching practices take into consideration learners' needs as the starting point to discuss what human 
rights are, and the role of human rights in their particular circumstances in order to persuade them of their actual relevance.

Eric's teaching strategies, on the other hand, appealed to the benefits of implementing human rights for the participants' work and professional responsibilities. For him, this was the best way to interest participants in the subject and, at the same time, emphasize the operational and practical aspects of human rights. Eric insisted on the applicability of human rights in all his programs by translating legal instruments and resolutions of human rights cases into specific responsibilities for judges and prosecutors, favouring an interactive approach and building upon participant experiences. He believed that, with greater interaction and examples that relate closely to participants, it was easier to engage them in the subject. One concrete strategy that he used regularly was the analysis of legal cases, either about human rights or that have been resolved using the new judicial system, which is rights-based. ${ }^{62} \mathrm{By}$ doing so Eric was able to use his previous experiences as a legal practitioner to focus on the challenges that judges, lawyers and prosecutors face in the implementation of the legal framework of human rights in Mexico.

Now resolutions by judges are starting to appear that are adopting the [human rights based] perspective. The idea is to use them [in the sessions] to analyze and discuss them with the participants so they can see that it is possible to apply this perspective (Eric, semi- structured interview).

The analysis of legal cases is key for Eric, since he can take advantage of the experience of participants, use their contributions as triggers for group reflection, and encourage participants to propose different resolutions or alternative rulings. This exercise helps judges and prosecutors to develop the necessary skills for the analysis of such cases through a rights-based perspective as it empowers them to implement this perspective in their own practice.

The approaches of the educators to HRE had significant similarities despite working with considerably different populations. Not only have they adapted the content and strategies used in the programs according to learners' needs, but all three educators favoured a pragmatic approach to HRE. This approach was translated into different teaching strategies and methods, from analysis of court rulings in the case of Eric, to Oscar's analysis of cases of human rights violations committed by the army, or Anna's use of roleplaying games to encourage children to become more empathic. In all cases, the emphasis was on the implementation of human rights, rather than on the development of factual learning on the subject, as well as being focused on fostering positive attitudes towards human rights. As a result, the three educators agreed that their professional practices focused mostly on persuading learners about the relevance and significance of human rights. They all felt

62 Mexico had a mixed judicial system until 2008, when an accusatory-adversarial system was implemented as a result of a national reform of the criminal justice system. 
it was necessary to first convince individuals that human rights matter, before teaching them how to put them into practice.

\section{Facing Professional Challenges}

The three educators drew on their personal experiences to discuss what they considered to be the main challenges faced in HRE in Mexico, and the impacts of said challenges on their professional knowledge and practices. The problems identified were similar and mostly related to three issues: 1) the skeptical attitudes of the populations they work with; 2) the context of violence in Mexico; and 3) the complexity of implementing HRE programs in the country. For instance, all three educators made several references to negative attitudes and widespread mistrust and skepticism towards human rights, not only on the part of participants attending HRE programs but also on the part of the Mexican population in general. This generalized disbelief is the reason why Eric highlighted the need to develop persuasive skills as a core element of his professional knowledge as an educator, so that he can convince individuals as well as organizations about the importance and significance of human rights. This is not a simple task, convincing individuals to change their personal and professional practices or promoting institutional change is especially challenging:

In many cases there is still a lot of ignorance, but I believe that there is also a lot of skepticism [about human rights]. I mean, people do not believe that this [new, rights-based judicial] system will solve anything or that it is any different from the previous one, that it can resolve some of the problems. Then what I need to do is to keep on encouraging people to truly believe in these issues, to believe that there is an opportunity [to change things]. It's not that [human rights] are a panacea, nor that they will resolve all our problems, but they give us new alternatives (Eric, semi-structured interview).

Eric recognizes that one of the main challenges of HRE regarding the skepticism and mistrust towards human rights relates to the profile of the participants it is aimed at addressing. He has found that public servants, judges and prosecutors with more years of experience are those who find it most difficult to accept the discourse of human rights, or see the value in their practice, whereas younger generations tend to be more receptive. The main challenge for Eric was to develop programs that would be capable of convincing the most skeptical groups, regardless of their longevity in their profession or their rank as public servants.

Similarly, Oscar explained that there are a lot of misconceptions about human rights amongst soldiers and police officers which make his teaching practice more challenging. He argued that it is common amongst these populations to consider human rights as mechanisms that demerit their authority 
and hinder their work by protecting criminals and freeing guilty prisoners. Such misconceptions make it difficult for Oscar to convince soldiers and police officers that these rights can also protect them, and be useful in their professional practice. According to Oscar, the first step is to listen attentively to their reasons for objecting to the discourse of human rights and to understand the professional challenges they face as the result of their work. For him, a way of reducing the skepticism amongst these populations is to direct HRE programs at mid and higher ranking professionals, because if they can be convinced about the relevance of these rights for their work and regular operations, they could have a "multiplier effect" on lower ranking officers. By doing so, it would become possible to have a greater impact on the prevention of human rights violations by members of these populations. Even though the military and police officers can be skeptical groups, Oscar was convinced about the long-term benefits that HRE can bring to them. He argued that his teaching practices have improved as a result of his work in trying to convince these groups about the relevance of human rights for their personal and professional lives.

Oscar and Eric discussed how violence and human rights violations across Mexico make it much more difficult for them to persuade participants about the importance of respecting and protecting these rights in their professional practice. Anna believes the high levels of violence that are increasingly affecting young people and children in the country makes it difficult for them to develop empathy or relate to ideas of social justice. Anna stated that the environment and social structures for most of the children and young people in Mexico are counterproductive to HRE, either because of the lack of respect for human rights or because of the obstruction of their exercise. For all three educators, the most difficult challenge in their profession remains how to teach and persuade individuals about the importance and value of human rights in their lives in a country where these rights are violated on a daily basis.

Finally, some of the challenges educators identified were related to the process of implementing HRE programs, from the lack of training needs assessments to their inability to evaluate their efficiency or measure the social impact of their work. Also, the lack of relevant training in HRE or examples of good practices for educators makes it difficult for them to develop their professional knowledge, clearly define their teaching objectives and learn the necessary skills to reach them. For instance, Oscar constantly felt he was an "improvised" educator that learned to teach human rights "on-the-go" due to the absence of training programs and institutional support for his career development. He tended to be insecure about his teaching practices because despite his own knowledge of the content of human rights, he has difficulties in conveying his knowledge and persuading participants efficiently.

All three educators agreed on the importance of the transformational nature of HRE programs; however, implementing transformational programs 
presents a challenge in assessing both their teaching practices and participants' learning. Eric also highlighted the difficulty of developing participatory programs to coordinate between society and grassroots movements, which makes it is difficult to assess the social impact of HRE. Anna, for her part, affirmed that the transformational purpose of HRE was almost impossible to achieve considering the limited time she has with each group, and the lack of resources for these programs. Even after setting more realistic objectives and lowering expectations for her own programs, this shortage of resources that makes it difficult for Anna to conduct an in-depth assessment of the program's impact or do follow-up with participants. Similarly, Oscar questioned the assessment within HRE, considering the objectives they have established unrealistic, and the groups they reach out to as difficult. His concerns relate to the capacity of educators to evaluate if participants have "fully learned" human rights and understand the transformational implications of such learning:

How can I know if the participants indeed are changing their own perspective [towards human rights], if they have changed their views? How can I possibly know if what I am teaching them will help to prevent human rights violations? (Oscar, semi-structured interview).

His concern is not only about the "measurement" of human rights learning for each participant, but also about the overall effectiveness of the educational programs and the evaluation of their social and institutional impacts over the short and long term. As Oscar explained, the problem is in establishing a correlation between what could be considered good outcomes - such as a decrease in human rights violations - and the educational programs and activities. For all three educators, then, the assessment of human rights programs remains a major challenge that, regardless of their experience, was difficult to overcome, especially since it involves institutional views on the subject which can often conflict with their own. For example, whereas the National Human Rights Commission grounds the assessment of HRE programs on the number of courses taught and participants present, the State Human Rights Commission is more concerned about the reputation of the programs it delivers, while the local NGO is more attuned to the political capital they can develop as a result of their programs. This contrast was evident in the way each institution reported their results in HRE:

For this reason, in 2013 7,394 training events were conducted, representing an increase of 589\% compared to the 1,073 activities in 2009.

Institution A - Annual Report

The [Institution] has a backup and a history of over 20 years of work and dedication to protecting, promoting and strengthening human rights in the 
Esta revista forma parte del acervo de la Biblioteca Jurídica Virtual del Instituto de Investigaciones Jurídicas de la UNAM

city. Throughout this time it has established itself as a clear leader within the public human rights, not only nationally but internationally.

Institution B - Annual Report

[...] Gather evidence on institutional politics and practices against human rights, to denounce the power structures and authoritarian practices of the government. Develop proposals to transform public institutions, empower civil actors and encourage them to participate in public affairs.

Institution C - Website

Despite these challenges, the three educators were convinced of the importance of HRE and training as a means of preventing further violations and abuses, and in achieving a culture of respect for human rights. Anna and Eric believe that, through HRE, they are able to empower individuals and change social structures in Mexico that impede the exercise of these rights. For both of them, HRE is an effective tool in promoting social justice. Oscar, on the other hand, was more cautious about the effects and possible outcomes of HRE. Even though he is convinced about the importance of human rights, he believes it is necessary to maintain a critical attitude towards HRE and the persuasion it requires, in order to avoid any sort of "indoctrination." For Oscar, being critical about their own profession is the only way practitioners can identify the limitations of human rights and HRE but also about their own strengths and areas of opportunity as educators. Oscar's apprehension regarding HRE focused more on its current implementation in Mexico and how it is assessed rather than its educational objectives or aims. Even though Anna and Eric identified some challenges with its implementation, they tended to maintain a more optimistic attitude towards HRE. Beyond their criticisms and the challenges each one faced, the three educators considered HRE a valuable and worthwhile attempt to significantly change individual and social realities in Mexico.

\section{Discussion and Conclusions}

The purpose of this article was to explore the professional knowledge and practices of human rights educators, in order to understand their impact on the development, implementation, and assessment of HRE programs in Mexico. As the findings of this cross-case analysis show, there are similarities in the way the three educators developed their professional knowledge, beyond the uniqueness of each case and the particular process of each educator. One of these similarities is with regards to the kind of knowledge educators need to teach human rights, as it is evident from educators' accounts and observations of their practice, that it is much more complex and challenging than simply having familiarity with international instruments, national poli- 
cies or human rights legislation. Professional knowledge appears to demand a deep understanding of the issue of human rights from an interdisciplinary perspective, which was a challenge for all educators regardless of their level of familiarity with the subject. As the educators noted, they each had to develop a subject-matter understanding that could be conveyed in a significant and relevant manner to diverse populations. This finding is consistent with previous research about teaching human rights ${ }^{63}$ emphasizing how educators must deal with the complexity of human rights definitions, meanings and approaches in order to make sense of this subject prior to teaching it. The three cases examined in this article show the diverse ways in which educators make sense of human rights, and the different nuances of their own definitions. This cross-case study shows that in practice, contrasting teaching strategies and objectives for HRE programs are grounded in educators' individual views, even though in theory the educators share similar aims.

Evidence from the cross-case analysis confirms that educators' professional knowledge also encompass pedagogical knowledge. ${ }^{64}$ This knowledge covered learning processes, teaching practices and methods needed to transform what educators teach -human rights- into significant and meaningful content for learners. In particular, educators' pedagogical knowledge focuses on teaching strategies and methods specific to the subject of human rights, inclusive of its complexity and critiques. Notions of how learners learn, class management and lesson planning are also important. Such pedagogical knowledge can be found among educators teaching in other disciplines ${ }^{65}$ and is consistent with previous research into teachers' knowledge, ${ }^{66}$ which suggests knowing a subject is not sufficient for teaching it. The three cases examined above demonstrate that constructing a sophisticated understanding of the issues as well as building pedagogical knowledge are necessary conditions to teach about and for human rights.

According to the findings of the three cases, the nature of professional knowledge in the field of HRE is experiential, ${ }^{67}$ implying that both the con-

63 Rendel, supra note 26.

64 Lee S. Shulman, Those Who Understand: Knowledge Growth in Teaching, 15 EDuc. Res. 4-14 (1986).

65 Examining Pedagogical Content Knowledge, (Julie Gess-Newsome \& Norman G. Lederman eds., 2002); S Brown \& Donald MaIntyre, Making Sense of Teaching (1993); Punya Mishra \& Matthew J. Koehler, Technological pedagogical content knowledge: A framework for teacher knowledge, 108 Teach. Coll. Rec. 1017-1054 (2006).

66 Deborah Loewenberg Ball, Mark Hoover Thames \& Geoffrey Phelps, Content Knowledge for Teaching: What Makes It Special?, 59 J. TeAch. Educ. 389-407 (2008).

67 David A. Kolb, Experiential Learning: Experience as the Source of Learning and Development (1984); Ruth Heilbronn, The Reflective Practitioner, in Critical Practice in Teacher Education 29-38 (Ruth Heilbronn \& John Yandell eds., 2010); Max Van Manen, Can Teaching Be Taught? or Are Real Teachers Found or Made?, 9 Phenomenol. + Pedagog. 182 (1991). 
tent and the pedagogical aspects of this knowledge can only develop through the experience acquired by educators. In this sense, educators' own teaching practices derive not only from their professional knowledge, but also inform and refine it, as earlier studies on professional knowledge in teaching suggest. ${ }^{68}$ Connelly, Clandinin, and Fang He suggest that educators' professional knowledge is the sum of their own experiences rather than objective or independent factors ${ }^{69}$ which is consistent with the findings of the present crosscase analysis. The teaching experiences of the three practitioners interviewed for this article lead them to refine their pedagogical approach and to reflect on broader educational issues such as their teaching style, the strategies they employ as teachers, and the purpose of their professional practice.

Nevertheless, the impact of the educators' professional experiences and teaching practices goes beyond "reflection-in-action"70 and influences their views on human rights, something which seem to be a distinctive feature of the field of HRE. Their understanding of human rights is grounded mainly in their experiences of implementing educational programs and teaching this subject in a particular context, to a specific target group. Their practices shaped their knowledge on the subject of human rights and helped them to develop a more sophisticated understanding of the advantages, limitations and applicability of human rights in Mexico. In addition, in reflecting on their experiences and practices, practitioners were able to constantly assess and adapt their own professional knowledge to maintain its relevance and pertinence, which is key in Mexico due to the generalized mistrust towards human rights because of widespread violence. Teaching human rights then becomes a process of constant application, evaluation and construction of professional knowledge through practice. ${ }^{71}$ As this cross-case analysis shows, educators in Mexico learn to teach by teaching, and they construct knowledge through reflection upon their own concrete teaching experiences.

These findings have significant implications for understanding the professional profile required to implement HRE programs in Mexico, and can be used to inform the design of professional training programs for human rights educators in Mexico. By understanding that the development of professional knowledge in this field is first and foremost an through an experiential learning process, ${ }^{72}$ the need to establish mentoring programs becomes evident. Novice educators can benefit from access to mentors and experienced edu-

68 Kinsella \& Pitman, supra note 48.

69 Michael Connelly, Jean Clandinin \& Ming Fang He, Teachers’ personal practical knowledge on the professional knowledge landscape, 13 Teach. Teach. Educ. 665-674 (1997).

70 Susan Hart, Thinking through Teaching (2000); Terence H. McLaughlin, Beyond the Reflective Teacher, 31 Educ. Philos. Theory 9-25 (1999); Donald A. Schön, The Reflective Practitioner: How Professionals Think in Action (1983).

71 Kinsella \& Pitman, supra note 48.

72 Abraham Magendzo, Pedagogy of human rights education: a Latin American perspective, 16 Intercult. Educ. 137-143 (2005). 
cators while they learn to teach; both by getting additional support and by sharing best practices, reflecting and thinking critically together about human rights and how to address the challenges of their practice. The creation of such communities of practice has proved to be influential in how educators in other fields develop professional knowledge. ${ }^{73}$ Mentoring programs could enable professionals from different fields to consider teaching human rights as a career, as it would provide them with the opportunity to develop the necessary knowledge, fill any content or pedagogical gaps and learning from the experiences of others in a safe space. Such professional diversity could enrich HRE programs, especially in the Mexican context, by fostering an interdisciplinary teaching approach and using practitioners' experiences in their own fields to make human rights relevant for the challenges the different groups of learners face. This approach could make HRE programs more pragmatically relevant, which in turn, could help to counteract the mistrust and widespread skepticism towards these rights by showing the scope and possibilities of their application.

The findings of this cross-case analysis also provide examples of how HRE is implemented in a context as violent as Mexico, in which human rights are not upheld. Educators focus much more on raising awareness and convincing learners about the relevance and significance of human rights rather than conveying information or providing them with knowledge about these rights and for their exercise. Such findings question the emphasis in previous models of HRE on the content or the development of skills, ${ }^{74}$ showing instead that the work of educators in these "hellish" contexts is more challenging than skills development. ${ }^{75} \mathrm{~A}$ focus on persuasion is paramount due to the generalized mistrust and skepticism towards human rights in Mexico, which is an understandable reaction considering that violence is normalized, and human rights violations and abuses occur on a daily basis. In this sense, the educators' strong commitment to human rights seems to be a core element of their professional knowledge as well as a necessary condition for their teaching practices, since it is easier to persuade learners about something they already believe themselves. However, and considering the role of reflection for their professional knowledge, it is important that educators also have spaces to think critically about these rights, to consider learners' objections and to reflect on the strengths and weakness of human rights as well as the possible alternatives to address their limitations.

Overall, practitioners responsible for teaching human rights in Mexico present a flexible and dynamic kind of professional knowledge that is relevant

\footnotetext{
73 Ruth Heilbronn, Teacher Education and the Development of PracticalJudgement

74 Tibbitts, supra note 18; Lohrenscheit, supra note 29.

75 Obiora Chinedu Okafor \& Shedrack C Agbakwa, Re-Imagining International Human Rights Education in Our Time : Beyond Three Constitutive Orthodoxies, 14 Leiden J. Int. Law 563-590 (2001).
} (2008). 
not only contextually, but that is constructed and refined through their own experiences. Professional knowledge and experiential learning allow practitioners to teach human rights while addressing the needs of the Mexican context in a meaningful way, incorporating their previous teaching experiences and informed by learners' particular needs. It also allows educators to translate abstract guidelines and principles of human rights into specific decision-making criteria for participants in educational and training programs in ways that can foster a commitment to human rights. This does not necessarily mean practitioners have all the answers on how to implement HRE programs in Mexico, but it indicates that professional knowledge and experience provide practitioners with an effective framework to guide their actions. 